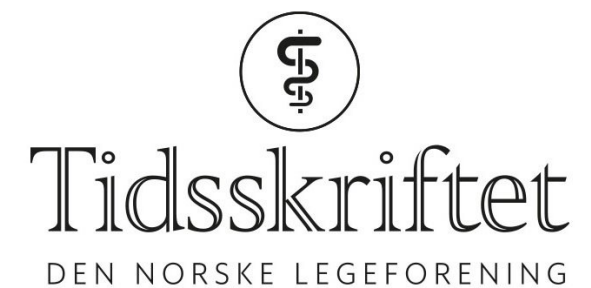

DEN NORSKE LEGEFORENING

\title{
Blandet virkelighet - ny bildeteknologi i klinisk utprøving
}

KRONIKK

\section{HENRIK BRUN}

E-post: hbrun@ous-hf.no

Henrik Brun er overlege ved Barnekardiologisk avdeling, Oslo universitetssykehus, Rikshospitalet og postdoktorstipendiat ved Intervensjonssenteret, Oslo universitetssykehus.

Forfatteren har fylt ut ICMJE-skjemaet og oppgir følgende interessekonflikter: Han er medoppfinner av teknologi lisensiert til selskapet HoloCare AS og eier aksjer i selskapet indirekte via Inven2 AS.

\section{EGIDIJUS PELANIS}

Egidijus Pelanis er lege og forsker ved Intervensjonssenteret, Oslo universitetssykehus og ph.d.stipendiat ved Institutt for klinisk medisin, Universitetet i Oslo.

Forfatteren har fylt ut ICMJE-skjemaet og oppgir følgende interessekonflikter: Han er medoppfinner av teknologi lisensiert til selskapet HoloCare AS og eier aksjer i selskapet indirekte via Invenz AS.

\section{OLA WIIG}

Ola Wiig er overlege ved Ortopedisk avdeling, Oslo universitetssykehus, Rikshospitalet. Forfatteren har fylt ut ICMJE-skjemaet og oppgir følgende interessekonflikter: Han er medoppfinner av teknologi lisensiert til selskapet HoloCare AS og eier aksjer i selskapet indirekte via Inven2 AS.

\section{JAVIER ARMANDO LUZON}

Javier Armando Luzon er lege i spesialisering ved Gastrokirurgisk avdeling, Akershus universitetssykehus og klinisk ph.d.-stipendiat og lektor ved Institutt for klinisk medisin, Universitetet i Oslo.

Forfatteren har fylt ut ICMJE-skjemaet og oppgir følgende interessekonflikter: Han er medoppfinner av teknologi lisensiert til selskapet HoloCare AS og eier aksjer i selskapet indirekte via Inven2 AS.

\section{SIGURD BIRKELAND}

Sigurd Birkeland er overlege ved Seksjon for medfødte hjertefeil, Oslo universitetssykehus, Rikshospitalet.

Forfatteren har fylt ut ICMJE-skjemaet og oppgir ingen interessekonflikter.

\section{RAHUL PRASANNA KUMAR}

Rahul Prasanna Kumar er ingeniør og postdoktorstipendiat ved Intervensjonssenteret, Oslo universitetssykehus.

Forfatteren har fylt ut ICMJE-skjemaet og oppgir følgende interessekonflikter: Han er medoppfinner av teknologi lisensiert til selskapet HoloCare AS og eier aksjer i selskapet indirekte via Invenz AS.

\section{ÅSMUND AVDEM FRETLAND}

Åsmund Avdem Fretland er overlege ved Intervensjonssenteret og Seksjon for lever- og pancreaskirurgi, Oslo universitetssykehus, Rikshospitalet. Forfatteren har fylt ut ICMJE-skjemaet og oppgiringen interessekonflikter. 
Kathrine Rydén Suther er overlege ved Barneradiologisk seksjon, Oslo universitetssykehus, Rikshospitalet.

Forfatteren har fylt ut ICMJE-skjemaet og oppgiringen interessekonflikter.

\section{BJØRN EDWIN}

Bjørn Edwin er overlege ved Intervensjonssenteret og Seksjon for lever- og pancreaskirurgi, Oslo universitetssykehus, Rikshospitalet og professor ved Institutt for klinisk medisin, Universitetet i Oslo. Forfatteren har fylt ut ICMJE-skjemaet og oppgir følgende interessekonflikter: Han er medoppfinner av teknologi lisensiert til selskapet HoloCare AS og eier aksjer i selskapet indirekte via Invenz AS.

\section{OLE JACOB ELLE}

Ole Jacob Elle er leder for Seksjon for kybernetikk og medisinsk bildebehandling, Intervensjonssenteret, Oslo universitetssykehus og professor ved Institutt for informatikk, Universitetet i Oslo.

Forfatteren har fylt ut ICMJE-skjemaet og oppgir følgende interessekonflikter: Han er medoppfinner av teknologi lisensiert til selskapet HoloCare AS og eier aksjer i selskapet indirekte via Invenz AS.

Nye metoder for holografisk bildevisning gir ekte tredimensjonal opplevelse av medisinske bilder. Teknikken vekker stor interesse på kirurgiske fagfelter.

Vi er vant til at diagnostisk bildefremstilling av kroppen gjøres på todimensjonal (2D) skjerm, men en tredimensjonal (3D) fremstilling gjør det lettere å se relasjonen mellom strukturer. Virkelighetsnær bildeteknologi er under stadig utvikling. Et eksempel er blandet virkelighet (mixed reality), der virkeligheten og en virtuell virkelighet smelter sammen og blandes, og man kan få en holografisk visning med briller som inkluderer omgivelsene.

Med økende bildekvalitet og bedre programvare er det enklere å lage detaljerte 3D-bilder som kan gjøre det lettere å forstå lokalisasjon og form på en patologisk forandring $\mathrm{i}$ kroppen. Denne type bilder vises vanligvis på en flat dataskjerm med begrenset dybdeopplevelse. Holografisk visning av organet kan gi en raskere og dypere forståelse både av problemet og dets løsning.

Holografiske bilder av misdannelser i hodeskallen ble beskrevet i 1988 (1). Eksperimentelle artikler innen ryggkirurgi (2) og 3D-ultralyd av hjertet (3) kom i 199o-årene, og bevegelsen fra $2 \mathrm{D}$ til $3 \mathrm{D}$ slo først an innen kirurgi. Planlegging i tre dimensjoner er krevende, f.eks. for et inngrep i hjertet (4), og bruk av hologram i simulering av vanskelige prosedyrer er derfor foreslått til opplæring.

Tidlig holografisk teknologi var tung i bruk, og datakapasiteten var begrenset. Utstyret for virkelighetsnær 3D-opplevelse er blitt mer brukervennlig og effektivt og tas i bruk innen mange fagfelter. Vi beskriver utviklingen av teknologien blandet virkelighet (mixed reality, MR) i medisinsk diagnostikk og behandling og hvordan arbeidet innen mange fagområder kan forandres.

\section{Blandet virkelighet i klinisk utprøving}

Ved Oslo universitetssykehus, Rikshospitalet og Akershus universitetssykehus har blandet virkelighet med holografiske briller vært i eksperimentell klinisk bruk siden 2017. Studieområder er leverkirurgi, medfødte hjertefeil, tykktarmskreft og hoftelidelser (figur 1). Grunnlag for hologrammene er CT-, MR- og ultralydbilder, og bildene prosesseres i økende grad med støtte fra kunstig intelligens. Blandet virkelighet åpner også for nye måter å kommunisere på, for eksempel kan en holografisk behandler nå pasienter som er isolert eller langt unna.

\section{Planlegging, navigering og visualisering}


Reparasjon av komplekse medfødte hjertefeil stiller store krav til 3D-forestillingsevne i både planlegging og gjennomføring. Kritiske strukturer som kransarterier og store kar skal flyttes og hjerteklaffer rekonstrueres og repareres, kanskje allerede i nyfødtperioden. Tradisjonelt har planlegging av slike inngrep vært basert på evnen til å danne seg et 3Dbilde av pasientens anatomi fra snittbilder. Denne evnen varierer fra individ til individ (5). Selv med detaljert terminologi er det krevende å kommunisere om problem og løsning.

3D-rekonstruksjon av CT- eller MR-bilder på flatskjerm har forenklet forståelsen av for eksempel aortamisdannelser. Virkelig 3 D-opplevelse ble først mulig med hologram og 3 Dutskrifter, f.eks. av individuelle hjertemodeller. Utvidet virkelighet sammenliknes nå med 3D-utskrifter for å definere bruksområder (6). Oslo universitetssykehus fikk i 2017 briller med programvare for blandet virkelighet. Hjulpet av dataingeniører kunne man studere datamodellene som brukes for 3D-utskrifter - nå som hologram.

Over 50 pasienter er inkludert i en studie av nytten av holografisk visualisering før hjertekirurgi. Tidlige resultater viser at teknologien er enkel i bruk og gir god dybdeopplevelse (7). Erfaringer fra enkelttilfeller viser at hologram kan forenkle forståelsen av komplekse medfødte hjertemisdannelser. Metoden har foreløpig utfordringer når det gjelder for eksempel avstandsmåling. Tynne og bevegelige strukturer som hjerteklaffer er tidkrevende å modellere. Holografisk modellering av implantater for lukking av ventrikkelseptumdefekter er nå under testing. Videre utvikling sikter mot fusjon av bildemodaliteter og navigering i hologrammer under intervensjoner. Nylig er det beskrevet bruk av ulike teknologier for 3 D-visualisering av medfødte hjertefeil (6).

\section{LEVERKIRURG I}

Laparoskopisk vevsbesparende leverkirurgi ble først brukt for mer enn 20 år siden og er nå en etablert kirurgisk teknikk for å fjerne spredningssvulster fra tarmkreft. Prinsippet er å fjerne svulsten med god nok margin og spare så mye frisk lever som mulig. Pasienten får en større rest av lever, noe som reduserer faren for komplikasjoner. Om lag halvparten får tilbakefall, og metoden forenkler behandling av disse (8). I dag har kirurger begrensede muligheter til å planlegge leveroperasjoner.

En pasientspesifikk 3 D-modell av leveren, med blodårer og svulster, viser relevant operasjonsforberedende informasjon og gir oversikt over forhold mellom anatomiske strukturer. Med avansert programvare kan en slik 3 D-modell gi økt mulighet til å planlegge og formidle komplekse operasjonsplaner. En av fordelene med blandet virkelighet, er at utstyret er mobilt. Hologrammene kan brukes fleksibelt på tverrfaglige møter og på operasjonsstua. Vi fant at det tar kortere tid å finne en leversvulsts lokalisasjon med en holografisk modell enn med MR-bilder (9). Løsningen brukes nå i forskning for å planlegge komplekse prosedyrer, men kan i fremtiden bli en del av den kliniske hverdagen.

Neste trinn er å bruke denne teknologien under operasjon, som et interaktivt kart med oppdatering underveis. Dette leder mot full funksjonalitet for navigasjon, hvor instrumentene spores og gjengis i 3 D-modellen for å vise hvor man er på kartet.

\section{TUMORKIRURGI I TYKKTARM}

Ved kurativt siktemål gjennomføres fjerning av tykktarmsegment med tumor og intakt krøs med regionale lymfeknuter. Ved Akershus universitetssykehus gjennomføres utvidet mesenterektomi for tykk- og tynntarmskreft, der man deler av mesenterielle kar ved avgangen. Målet med operasjonsmetoden er å fjerne flere lymfeknuter og oppnå en mer radikal behandling i håp om å redusere risiko for tilbakefall.

Store variasjoner i karforløp krever detaljert kartlegging. Til dette brukes høyoppløselige, kontrastforsterkede CT-bilder. Fra disse lages en detaljert 3D-fremstilling av kararkitekturen. Vanligvis blir disse rekonstruksjonene vist på papir eller skjerm, men de 
kan nå vises som 3D-printede modeller eller hologram (10). Nå testes det ut om også blandet virkelighet kan brukes. Erfaringene hittil er at 3D-modellene enkelt kan visualisere de anatomiske strukturene både pre- og intraoperativt. Målet er tryggere navigasjon under kreftkirurgi og mer individtilpasset behandling med skreddersydd onkologisk kirurgisk tilnærming (11).

Segmenteringsmetoden som lager 3D-modeller, må valideres før klinisk bruk, også med fremtidig hjelp av kunstig intelligens (11).

\section{ORTOPEDISK KIRURGI}

Deformiteter i hoften kan gi smerter og redusert bevegelighet. Dette er vanskelig å diagnostisere og utrede. Det tas vanligvis et røntgenbilde i to plan og en CT-undersøkelse. For å forstå anatomien bedre kan man lage 3D-rekonstruksjoner av bildene, men disse har til nå blitt vist som 2D-bilder på en skjerm uten informasjon om bevegelse. For å oppnå best mulig resultat etter en operasjon må man vite hvilke deler av hoften som kommer i knip og ved hvilke bevegelser dette skjer.

Ved bruk av holografisk teknologi med blandet virkelighet (12) kan vi gjøre en leddunders $\emptyset$ kelse der vi ser hvordan skjelettet beveger seg mens vi unders $\emptyset$ ker pasienten. CT-bilder av bekken og hofter brukes for å lage et hologram av bekkenet og hoftene. Hologrammet blir deretter plassert på pasientens eget lårben, hofteledd og bekken ved hjelp av mark ører og optisk sporingssystem og vil nå bevege seg når undersøkeren beveger pasientens ben. Slik kan man se hvilke bevegelsesinnskrenkninger som finnes og hvilke årsaker disse har, og pasienten kan gi uttrykk for hvilke bevegelser og leddposisjoner som er smertefulle. Dette gir ny informasjon om pasientens hoftelidelse og bedre grunnlag for å vurdere hvilken behandling som har effekt.

Vi har brukt denne undersøkelsesteknikken på utvalgte pasienter med senfølger av barnehoftesykdommer. Denne teknologiens potensial i ortopedisk kirurgi er stort. Vi arbeider med metoder som kan brukes til kirurgisk planlegging, der man med holografiske fremstillinger av ben og ledd kan legge virtuelle kirurgiske snittplan gjennom knokkelen og rekonstruere skjelettdeformiteter i blandet virkelighet. Muligheten for bruk under operasjoner er stor, da «sanntids røntgensyn» kan gi raskere, mer nøyaktig, mindre invasiv og tryggere kirurgi.

\section{Konklusjon}

Blandet virkelighet er en teknologi som kan vise hologrammer laget av medisinske bilder samtidig med virkeligheten rundt oss (for eksempel pasienten, legen og instrumentene). Med sporingsteknikk oppnås effekter som røntgensyn og 3 D-navigering under kirurgi. Bruken av blandet virkelighet i medisinen er fortsatt i en tidlig utviklingsfase og har store forventninger knyttet til seg. Automatisk produksjon av hologrammer med kunstig intelligens kan øke den kliniske nytten, men metoden må valideres innen hvert kliniske område for å avdekke begrensningene. Holografisk telemedisin er et spennende utviklingsområde som kan redusere behovet for ekspert- og pasienttransport, og virtuell legevisitt under epidemier kan redusere smittespredning og spare smittevernutstyr.

\section{LITTERATUR:}

1. Fujioka M, Ohyama N, Honda T et al. Holography of 3 D surface reconstructed CT images. J Comput Assist Tomogr 1988; 12: 175-8. [PubMed][CrossRef]

2. Benzel EC, Rupp FW, McCormack BM et al. A comparison of fluoroscopy and computed tomography-derived volumetric multiple exposure transmission holography for the guidance of lumbar pedicle screw insertion. Neurosurgery 1995; 37: 711-6. [PubMed][CrossRef]

3. Vannan MA, Cao QL, Pandian NG et al. Volumetric multiplexed transmission holography of the 
4. Bol Raap G, Koning AHJ, Scohy TV et al. Virtual reality 3D echocardiography in the assessment of tricuspid valve function after surgical closure of ventricular septal defect. Cardiovasc Ultrasound 2007; 5: 8. [PubMed][CrossRef]

5. Peters M. Sex differences and the factor of time in solving Vandenberg and Kuse mental rotation problems. Brain Cogn 2005; 57: 176-84. [PubMed][CrossRef]

6. Goo HW, Park SJ, Yoo SJ. Advanced medical use of three-dimensional imaging in congenital heart disease: Augmented reality, mixed reality, virtual reality, and three-dimensional printing. Korean J Radiol 2020; 21: 133-45. [PubMed][CrossRef]

7. Brun H, Bugge RAB, Suther LKR et al. Mixed reality holograms for heart surgery planning: first user experience in congenital heart disease. Eur Heart J Cardiovasc Imaging 2019; 20: 883-8. [PubMed][CrossRef]

8. Aghayan DL, Pelanis E, Avdem Fretland Å et al. Laparoscopic parenchyma-sparing liver resection for colorectal metastases. Radiol Oncol 2017; 52:36-41. [PubMed][CrossRef]

9. Pelanis E, Kumar RP, Aghayan DL et al. Use of mixed reality for improved spatial understanding of liver anatomy. Minim Invasive Ther Allied Technol 2020; 29:154-6o. [PubMed][CrossRef]

10. Luzon JA, Andersen BT, Stimec BV et al. Implementation of 3 D printed superior mesenteric vascular models for surgical planning and/or navigation in right colectomy with extended D3

mesenterectomy: comparison of virtual and physical models to the anatomy found at surgery. Surg Endosc 2019; 33: 567-75. [PubMed][CrossRef]

11. Sauer IM, Queisner M, Tang P et al. Mixed reality in visceral surgery: Development of a suitable workflow and evaluation of intraoperative use-cases. Ann Surg 2017; 266: 706-12. [PubMed][CrossRef]

12. Verhey JT, Haglin JM, Verhey EM et al. Virtual, augmented, and mixed reality applications in orthopedic surgery. Int J Med Robot 2020; 16: e2067. [PubMed][CrossRef]

Publisert: 23. november 2020. Tidsskr Nor Legeforen. DOI: 10.4045/tidsskr.20.0498

Mottatt 3.6.2020, første revisjon innsendt 7.9.2020, godkjent 21.10.2020.

(C) Tidsskrift for Den norske legeforening 2020. Lastet ned fra tidsskriftet.no 